\title{
PROBLEM-SOLVING APPROACH IN MULTIPLE REPRESENTATIONS OF QUALITATIVE AND QUANTITATIVE PROBLEMS IN KINEMATICS MOTION
}

\author{
Ade Tegar Saputra*1, Jumadi², Debora Wibiane Paramitha ${ }^{3}$, Siti Sarah ${ }^{4}$ \\ ${ }_{1,2}$ Physics Education Department, Yogyakarta State University, Kolombo Street Number 1 Karang Malang, Depok, \\ Sleman, Yogyakarta, Indonesia \\ ${ }^{3}$ Curriculum, Pedagogy, and Assessment, UCL Institute of Education, University College London, 20 Bedford Way \\ London WC1H 0AL \\ ${ }^{4}$ Physics Education Department, Sains Al-Quran University, Kalibeber Street Number 3 Wonosobo, Central Java \\ *Correspondence address: adetegar.2018@student.uny.ac.id
}

Received: January $28^{\text {nd }}, 2019$. Accepted: April 22 ${ }^{\text {nd }}, 2019$. Published: April $29^{\text {th }}, 2019$

\begin{abstract}
Abstrak: The study aims to find the approach used by students in solving physics problems with symbol and graph representations, and also to find out the student's approach to solving qualitative and quantitative questions. This is related to student good problem solvers use multiple representations to solve the problem. They use the qualitative and quantitative approach in a physics problem. The type of research conducted to find out this is quantitative descriptive. In this study, data were obtained by tests and interviews. We give four problems in kinematic motions to undergraduate students. The problem consists of a graphic and symbol representation of qualitative and quantitative problems. The result shows that the quantitative problem of symbol and graphic representation, all of the students only solve the problem without qualitative analysis. That proves in these problems all of the students become a novice problem solver in this problem. Different from it, $84 \%$ of students not only solve the qualitative physics problem in symbol representation problems with the qualitative approach but also, we solve with quantitative analysis. On the other hand, they only explain the graph representations problem with descriptions.
\end{abstract}

C 2019 Physics Education, UIN Raden Intan Lampung, Indonesia

Keywords: good problem-solvers, kinematic motions, multiple representations.

\section{INTRODUCTION}

Problem-solving in physics learning is one of an important factor in learning physics. It can be an indicator because we can know the understanding concepts in physics of student (Maries \& Singh, 2018; Teodorescu, Bennhold, Feldman, \& Medsker, 2013). Teachers, who have used many ways to improve it, try to make media, lesson plan, and teaching approach based on problem-solving (Malik, Ertikanto, \& Suyatna, 2015; Prastiwi, Sriyono, \& Nurhidayati, 2016; Ubaidillah, 2016). The function of this way is to decrease mindset, that to solve problems in physics just need to remember all equations and basic mathematics skills (Docktor, Strand, Mestre, \& Ross, 2015). Most students find it difficult to find complex and unstructured physics problems because in learning at school they always solve problems with a structured start by recording the known physical quantities, using the right equation and solving the equation in sequence (Leak, Rothwell, Olivera, Zwickl, \& Vosburg, 2017). Research conducted at 3 high schools in Malang about the causes of difficulties in solving problems in physics stated that $26 \%$ of students had difficulty understanding concepts and formulas, $18 \%$ had difficulty using formulas, $17 \%$ had difficulty analyzing graphs and diagrams, and $7 \%$ of students had difficulty in conclude the physics learning that has been done (Azizah, Yuliati, \& Latifah, 2015).

In physics problem solving, representations consist of graph, symbol, 
verbal, and diagram, which have an approach to solve them and to solve each problem in different representation depends on the ability of the students to understand every representation (Aviani \& Me, 2015). In physics problems, representation has several types including verbal or linguistic, diagrammatic, pictorial, graphic, symbolic, and mathematical forms. If students have the ability in many representations, it can be said that students have multirepresentation abilities (Hung \& Wu, 2018). Previous research proved that students who can translate verbal problems into diagrams have better problem-solving abilities than students who cannot translate the problem (Bollen, Kampen, Baily, Kelly, \& Cock, 2017).

Different approaches to solve qualitative and quantitative problems it is important for improving problem-solving abilities in physics problem-solving (Kustusch, 2016; Marshman \& Singh, 2015). If students prefer things related to calculus, they will tend to solve problems using quantitative methods, while for students who do not like calculus usually will tend to solve problems in a qualitative way (Susac, Bubic, Kazotti, Planinic, \& Palmovic, 2018). The good problem solver solves problems with a qualitative and quantitative approach in all kind problems, but the novice problem solver just solves the problem with a quantitative approach or just with calculus. The good problem solver, who have all the representation abilities, that name is multiple representations and evaluate their working with graphical analysis (Susac, Bubic, Martinjak, Planinic, \& Palmovic, 2017).

Indonesian students are only able to remember facts, terms, and scientific laws only to solve problems without being able to use reasoning analysis a problem that occurs in everyday life (Supeno, Subiki, \& Rohma, 2018). Therefore most students in Indonesian students consider physics to be something difficult because it uses too many formulas and must be memorized if it wants to solve problems in it (Azizah et al., 2015). This makes obstacles in solving problems using multiple representations (Nieminen, Savinainen, \& Viiri, 2010). The source of this problem is actually not only we can bestow on students, but the role of the teacher here is very important (Fahmi, 2017; Scherr, Plisch, \& Goertzen, 2017). Most teachers, in giving problems to students do not see problems in each category of representation (Bunawan, Setiawan, Rusli, \& Nahadi, 2015). Teachers sometimes only focus too much on problems that usually appear on the final exam. This causes students not to be accustomed to solving problems in various types of representations. The result is that students will be confused in solving problems in different representations, even though sometimes the questions are relatively easy (Bollen et al., 2017).

Sometimes in the minds of students is that we memorize them with physics formulas. When memorizing the physics formula completion with quantitative analysis will facilitate problem-solving because students are only looking for unknown values in the physics equation (Rusilowati, 2017). Problems in some representations are difficult to do with only a quantitative approach, sometimes requiring a qualitative approach (Docktor et al., 2015). For example, graphs and symbol representations, students need qualitative analytical skills to be able to imagine events that occur in problems.

Previous research conducted by (Ibrahim \& Rebello, 2012) found that students only manipulated equations in physics problems in various kinds of representations. Moreover, students rarely used qualitative solutions to solve physical problems. In the research conducted they used problems in symbol representation, graphics, and verbal with qualitative and quantitative questions in kinematics and energy ventures. In this study, researchers wanted to look at the problem-solving approach of prospective physics teachers 
who were studying. This is done because not only the problems found in students but also the teacher is one of the influential factors in developing problem-solving skills in physics (Ibrahim \& Rebello, 2012).

This research was conducted because in Indonesia, in general, it directly provides treatment for students to improve problemsolving skills. They rarely see what is needed by students. By knowing the problem-solving approach, we can provide appropriate treatment according to the needs of students. Students who are good at solving using a qualitative approach should be treated by encouraging students to understand formulas, while students who have a good understanding of calculus should be encouraged to understand something verbally.

\section{METHOD}

The purpose of this study is to describe the approach used in solving physics problems with various representations. So the type of research conducted is quantitative descriptive. This type of research will only describe the approach used by students in solving physics problems in various representations. Problems in graphic representations are two problems which one is quantitative problems, and another one is qualitative problems. Problems in symbol representations are two problems which one is quantitative problems, and another one is qualitative problems.

The quantitative problems are shown in figure 1 and 2 . Figure 1 is the problem in symbol representation, and another is the problem in graphical representation. Figure 1 is a matter of motion kinematics with a type of quantitative question. This problem is a type of symbol representation problem the student is asked to find the value of the speed and acceleration at a certain time. The response of this question can be variously explained in table 1 . Figure 2 is a matter of motion kinematics with a type of quantitative question. This problem is a type of graph representation problem, in this equation students, are asked to find the time value in the distance traveled from two different graphs, the first graph is a graph of distance with time and the second is a speed graph with distance. The problem will see the approach, which is used by students. This problem is designed for undergraduate students who have completed basic mechanics and physics courses. Problem 1, we get data, which is shown in table 1 . The data illustrates the problem-solving approach of an alternative problem in different representations. The approach indicators used by students are listed in table 1 in the approach section.

The equation of motion for an object moving along a straight horizontal path is found to be

$$
v_{x}(t)=3+2 t
$$

If the object was in motion for $5 \mathrm{~s}$, what is the distance travelled and acceleration during this time?

Figure 1. Quantitative problem in symbol representation (Ibrahim \& Rebello, 2012)

The motion of a truck along a straight horizontal path is shown by the graphs below. Determine the time taken and acceleration of the truck to complete the whole journey 


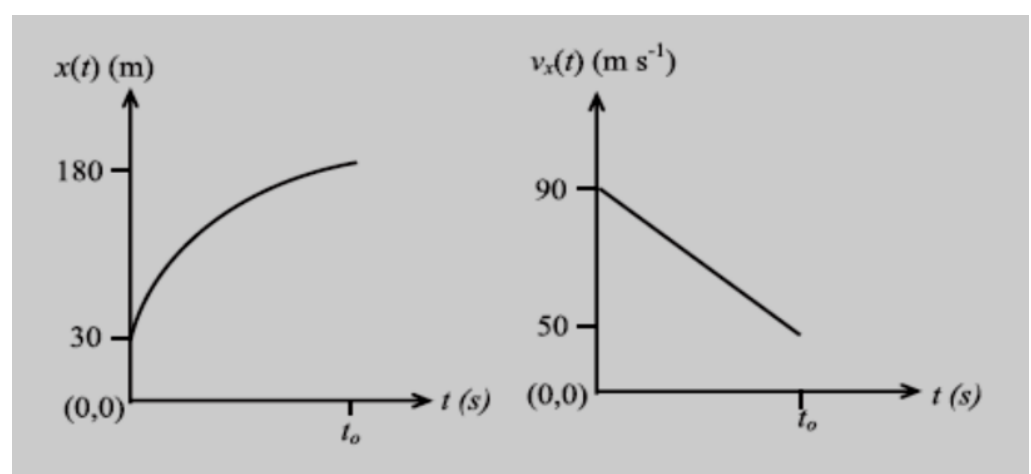

Figure 2. Quantitative problem in graphic representation (Ibrahim \& Rebello, 2012)

The quantitative problems are shown in figure 1 and 2 . Figure 1 is the problem in symbol representation, and another one is the problem in graphical representation. In figure 1 there is an equation of distance with time, in this problem students are expected to complete the problem by writing down what will happen to the motion of the object in accordance with the existing equation. This problem includes the problem of symbol representation with qualitative types of questions. Figure 4 is a problem of graph representation with a type of qualitative question. On this problem, there is a graph that shows the motion of an object. Students are asked to write down everything they know about the motion of the object. The graph is a graph of acceleration against time. In the graph, there are several events that students must describe. Not only described students should be able to analyze other quantities on the graph such as the speed and distance traveled by the object.

The instrument to see it is physics problems in kinematic motions, and it has validated by experts in physics. The problems consist of four problems in kinematic motions, that is two problems in qualitative and the other problems in qualitative. Students in this research are 12 undergraduate students at Yogyakarta State University, second grade and have done with fundamental physics lecture.
The method to take data is test and interview. The test is used to see problems approach in both of quantitative problems and qualitative problems. The interview is used to confirm the answers that have been done. This aims to find out whether students are working honestly, besides that it is also used to explore answers to qualitative questions (Ibrahim, Ding, Heckler, White, \& Badeau, 2017). In this research, the type of interview is an interview without a grid, this is due to the nature of interviews that only confirm and see honesty from students (Emigh, Passante, \& Shaffer, 2015). The researcher gives the student 20 minutes to answer all the problems. The researcher will take the student's answer when the time is up. If in the allotted time students have not finished working on the questions, questions will be asked at the time of the interview to be more in-depth. After that, students are interviewed by a researcher for about 10 minutes. Interviews were conducted in turns by recording using a recorder. Interviews were conducted in different rooms, and after students were interviewed, they were allowed to leave the research site. This is done so that the answers or questions at the interview are not known to students who have not been interviewed. Finally, the data will be analyzed with qualitative description. 
The equation of motion for an object moving along a straight horizontal path is given by

$$
x(t)=30+5 t+2 t^{2}
$$

Write down, in words, everything you can say about the motion of the object.

Figure 3. Qualitative Problem in Symbol Representation (Ibrahim \& Rebello, 2012)

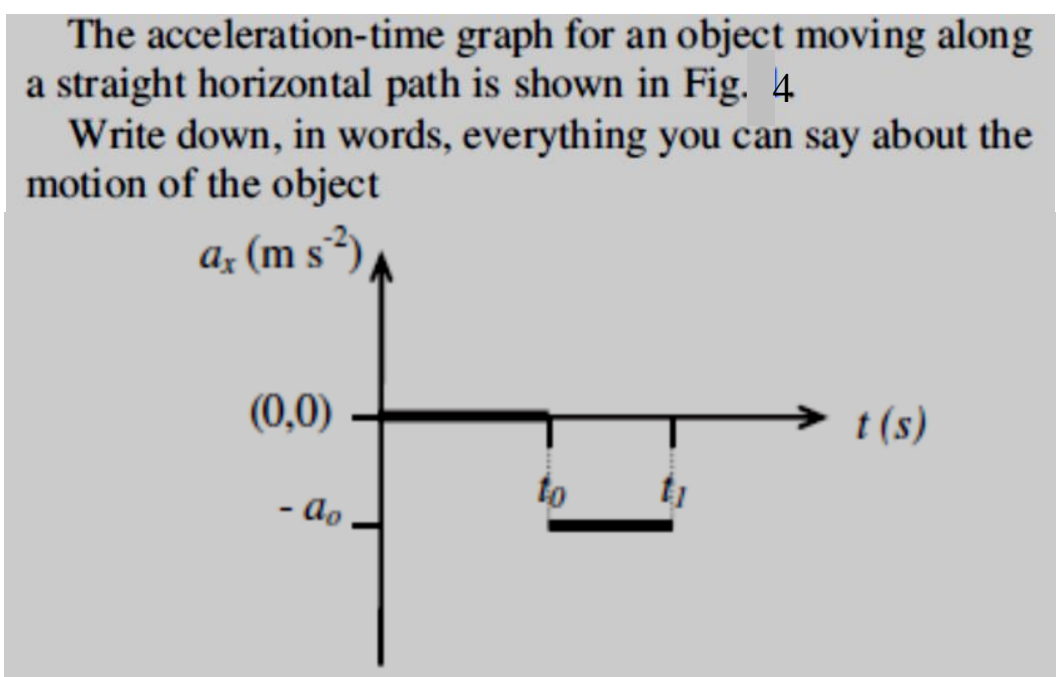

Figure 4. Qualitative Problem in Graphic Representation (Ibrahim \& Rebello, 2012)

This data will show how the students' approach is used to solve problems in several different problems in the solution. The data will be divided into two; the first data is about students' approach to solving graph representation problems. It will be explained whether students solve it with a qualitative and quantitative approach in solving quantitative problems or just solving them with just one approach. The second data will present data about the approach students use to solve symbol representation problems. It will load whether students can use the ability of multiple representations in working on the problem. This data will help teachers to teach with a multiple representation approach. Because of the importance of teaching physics that uses multiple representations, so it is expected that with this research the teacher will change the way he teaches with this approach.

\section{RESULTS AND DISCUSSION Problem Approaches in quantitative problems}

From table 1, we know that student just using a quantitative approach to solve quantitative problems in symbol representations. Although students can solve problems in many ways, they can explain the meaning from these symbols, that name is physical meaning (Prahani, Soegimin, \& Yuanita, 2015). In this case, students cannot explain the process in real life. For example, in second Newton laws will only be interpreted just about equations whereas in everyday life we can see if objects have a larger mass will have a movement that is slower than smaller mass if given the same force or can be said objects have large mass has a small acceleration value. So students are still confused if given a question concerning other quantities that can be determined from the equation on the problem, students 
are still confused to solve it (Fredlund, Linder, Airey, \& Linder, 2014; Heckler \& Scaife, 2015). In graphic representations, like in symbol representations, students only solve the problem with the quantitative approach.

Although the problem can solve with the area method, students choose with calculus manipulation to solve the problems. It is unfortunate that students can only solve problems using equation manipulation, even though problems can be solved using methods to find the area under the graph. Besides that most students also still find it difficult to interpret the graph (Christensen \& Thompson, 2012). So that some students lack time to solve the problem. The results of this study support previous research, where symbol and graph representations have more difficult difficulties than other types of representation as evidenced by the learning outcomes in both representations are lower than other representations (Yuwono, Mahardika, \& Gani, 2016). However, physical problems in symbol and graph representations, especially in quantitative problems, can be improved using the scaffolding approach. This approach helps students understand the problems of symbol representation and graphics (Lin, 2015). In addition to this, this study also shows the need for the use of a multirepresentation learning approach because it will be able to improve student representation skills (Widianingtiyas, Siswoyo, \& Bakri, 2017).

Table 1. Problem Approach in Quantitative Problem

\begin{tabular}{lcc}
\hline \multicolumn{1}{c}{ Approach } & \multicolumn{2}{c}{ Students } \\
\cline { 2 - 3 } & $\begin{array}{c}\text { Symbol } \\
\text { Representation }\end{array}$ & $\begin{array}{c}\text { Graphic } \\
\text { Representation }\end{array}$ \\
\hline $\begin{array}{l}\text { Using equations or calculus with } \\
\text { qualitative analysis }\end{array}$ & 0 & 0 \\
$\begin{array}{l}\text { Using equations or calculus without } \\
\text { qualitative analysis }\end{array}$ & 12 & 12 \\
\begin{tabular}{l} 
Looking for the area under the graph \\
\hline
\end{tabular} & 0 & 0 \\
\hline
\end{tabular}

Table 2. Problem Approach in Quantitative Problem

\begin{tabular}{lcc}
\hline \multicolumn{1}{c}{ Approach } & \multicolumn{2}{c}{ Students } \\
\cline { 2 - 3 } & $\begin{array}{c}\text { Symbol } \\
\text { Representation }\end{array}$ & $\begin{array}{c}\text { Graphic } \\
\text { Representation }\end{array}$ \\
\hline $\begin{array}{l}\text { Only Explanation of the symbol } \\
\text { /graph without manipulated } \\
\text { equations }\end{array}$ & 2 & 12 \\
$\begin{array}{l}\text { Only Explanation of the symbol } \\
\text { /graph with manipulated equations }\end{array}$ & 10 & 0 \\
\hline
\end{tabular}

\section{Problem Approaches in qualitative probem}

In the qualitative problems, the researcher wants to see, how students solve the graphics and symbol problem in qualitative problems and can students manipulate the symbol become new equations. This is expected because in qualitative questions students should also be able to complete quantitatively so they can master multiple representations. The data from students show in table 2.

From table 2 we know that ten students not only can explain the symbol from equations but also can manipulate equations become new equations using 
differential. The student can determine the velocity and acceleration equations through existing position equations using differentials for speed and double differential for acceleration. Besides explaining using mathematics students can also explain it by using story simulation if the time of an object is known. So that not only qualitative resolution capabilities are used but also the ability to solve problems quantitatively.

The other students just only explain the symbol. The student can only explain the equation without being able to make other equations such as velocity and acceleration equations. Besides that, they also have not been able to explain the events that occurred through illustrations. Even though in the interview session, researchers have provided feedback to direct students to quantitative solutions, students still cannot explain the equation into other quantitative equations.

Different from the symbol representation, in problems of graphic representations, all of the students just only explain the graph. They do not manipulate the graph to find equations. Students can explain the type of motion on each graph, such as in the first event of acceleration from a zero object so that objects move at a constant speed. In the second event the acceleration of the object decreases which means it will reduce the speed that exists but at a certain time, the acceleration returns to the board and finally rises again. Besides, that students cannot explain other things such as the equation that will be formed from the motion, the magnitude that will appear when the motion of the object is known its value and also an explanation of whether in the day-to-day event is there a graph. The results obtained were not much different from the research from (Ibrahim \& Rebello, 2012) conducted on 19 engineering undergraduate students. One of the causes of these problems is the unfamiliarity of students with questions in various representations.

\section{CONCLUSION AND SUGGESTION}

From this research, we know that in quantitative problems, graphics and symbol representations, students only solve the problems with the quantitative approach. It is showed that students in the research students could not solve physical problems in different representations. This is caused by several factors including do not understand with a concept in kinematic motions, or students are not familiar with the problems. For qualitative problems in symbol representations, $83 \%$ of students in research can solve the problem with both quantitative and qualitative approach which prove that they have good problem solver with multiple representations. On qualitative problems, students do show problem-solving skills using qualitative and quantitative solutions.

Different from it, in graphic representations, students become a novice problem solver, because they only explain the graph. The problem of graph representation is recognized by students as very difficult because students usually find this problem with a type of quantitative question so that when meeting questions in qualitative form students are not familiar. Not only cannot that because rarely find graphics problems in the type of qualitative questions students formulate a graph into a physical equation that shows the motion of objects. This must be changed so that students begin to get used to dealing with problems in types such as in this research. Students must be accustomed to solving problems with various types and in various kinds of representations. As explained in the introductions there are five types of representation that must be mastered by students in the business of having multiple representation abilities. This will be much related to students' problem-solving abilities.

\section{REFERENCES}

Aviani, I., \& Me, V. (2015). Drawing and using free body diagrams : Why it may 
be better not to decompose forces. 020137, $1-14$. https://doi.org/10.1103/PhysRevSTP ER.11.020137.

Azizah, R., Yuliati, L., \& Latifah, E. (2015). Kesulitan Pemecahan Masalah Fisika Pada Siswa SMA. Jurnal Penelitian Fisika Dan Aplikasinya (JPFA), 5(2), 44-50.

Bollen, L., Kampen, P. Van, Baily, C., Kelly, M., \& Cock, M. De. (2017). Student difficulties regarding symbolic and graphical representations of vector fields. Physical Review Physics Education Research, 13(020109), 1-17. https://doi.org/10.1103/PhysRevPhys EducRes.13.020109.

Bunawan, W., Setiawan, A., Rusli, A., \& Nahadi. (2015). Penilaian Pemahaman Representasi Grafik Materi Optika Geometri Menggunakan Tes Diagnostik. Cakrawala Pendidikan, 2(34), 257-267.

Christensen, W. M., \& Thompson, J. R. (2012). Investigating graphical representations of slope and derivative without a physics context. Physical Review Special Topics - Physics Education Research, 8(2), 1-5. https://doi.org/10.1103/PhysRevSTP ER.8.023101.

Docktor, J. L., Strand, N. E., Mestre, J. P., \& Ross, B. H. (2015). Conceptual problem solving in high school physics. 020106, 1-13. https://doi.org/10.1103/PhysRevSTP ER.11.020106.

Emigh, P. J., Passante, G., \& Shaffer, P. S. (2015). Student understanding of time dependence in quantum mechanics. Physical Review Special Topics Physics Education Research, 11(2), $1-12$.

https://doi.org/10.1103/PhysRevSTP ER.11.020112.

Fahmi, I. (2017). Pengaruh Kepribadian Dan Persepsi Kerja Guru Terhadap Organizational Citizenship Behavior
(OCB) Guru SMA Negeri SeKabupaten Karawang. Jurnal Pendidikan Pascasarjarana UNSIKA, 1(01), 112-121.

Fredlund, T., Linder, C., Airey, J., \& Linder, A. (2014). Unpacking physics representations: Towards an appreciation of disciplinary affordance. Physical Review Special Topics - Physics Education Research, 10(2), 1-13. https://doi.org/10.1103/PhysRevSTP ER.10.020129.

Heckler, A. F., \& Scaife, T. M. (2015). Adding and Subtracting Vectors: the Problem with the Arrow Representation. 11(1), 1-17. https://doi.org/10.1103/PhysRevSTP ER.11.010101.

Hung, C., \& Wu, H. (2018). Tenth graders ' problem-solving performance, selfefficacy, and perceptions of physics problems with different representational formats. Physical Review Physics Education Research, 14(2).

https://doi.org/10.1103/PhysRevPhys EducRes.14.020114.

Ibrahim, B., Ding, L., Heckler, A. F., White, D. R., \& Badeau, R. (2017). How students process equations in solving quantitative synthesis problems? Role of mathematical complexity in students' mathematical performance. Physical Review Physics Education Research, 13(2), $1-22$.

https://doi.org/10.1103/PhysRevPhys EducRes.13.020120

Ibrahim, B., \& Rebello, N. S. (2012). Representational task formats and problem solving strategies in kinematics and work. 8(1), 1-19. https://doi.org/10.1103/PhysRevSTP ER.8.010126.

Kustusch, M. B. (2016). Assessing the impact of representational and contextual problem features on student use of right-hand rules. 12(1), 
$1-22$.

https://doi.org/10.1103/PhysRevPhys EducRes.12.010102.

Leak, A. E., Rothwell, S. L., Olivera, J., Zwickl, B., \& Vosburg, J. (2017). Examining problem solving in physics-intensive $P h . D$. research. 13(2), $1-13$. https://doi.org/10.1103/PhysRevPhys EducRes.13.020101.

Lin, S. (2015). Effect of scaffolding on helping introductory physics students solve quantitative problems involving strong alternative conceptions. American Physical Society. 020105, $1-19$.

https://doi.org/10.1103/PhysRevSTP ER.11.020105.

Malik, A., Ertikanto, C., \& Suyatna, A. (2015). Deskripsi Kebutuhan HOTS Assesment pada Pembelajaran Fisika dengan Metode Inkuiri Terbimbing. Prosiding Seminar Nasional Fisika (E-Journal) SNF2015, 4, 1-4.

Maries, A., \& Singh, C. (2018). Case of two electrostatics problems: Can providing a diagram adversely impact introductory physics students problem solving performance? Physical Review Physics Education Research, 14(1). https://doi.org/10.1103/PhysRevPhys EducRes.14.010114.

Marshman, E., \& Singh, C. (2015). Framework for understanding the patterns of student difficulties in quantum mechanics. Physical Review Special Topics - Physics Education Research, 11(2), 1-26. https://doi.org/10.1103/PhysRevSTP ER.11.020119.

Nieminen, P., Savinainen, A., \& Viiri, J. (2010). Force concept inventorybased multiple-choice test for investigating students' representational consistency. Physical Review Special Topics - Physics Education Research, 6(2), 1-12. https://doi.org/10.1103/PhysRevSTP
ER.6.020109

Prahani, B. K., Soegimin, W. ., \& Yuanita, L. (2015). Pengembangan Perangkat Pembelajaran Fisika Model Inkuiri Terbimbing untuk Melatihkan Kemampuan Multi Representasi Siswa SMA. Pendidikan Sains Pascasarjana Universitas Negeri Surabaya, 4(2).

Prastiwi, A., Sriyono, \& Nurhidayati. (2016). Pengembangan Modul Fisika Berbasis Masalah Untuk Meningkatkan High Order Thinking Skills (HOTS) Siswa SMA. Jurnal Radiasi, 9(1 Oktober), 1-6.

Rusilowati, A. (2017). Pola pemecahan masalah berdasarkan representasi siswa dalam membangun pemahaman konsep fisika. 1(1), 1-7.

Scherr, R. E., Plisch, M., \& Goertzen, R. M. (2017). Sustaining Physics Teacher Education Coalition programs in physics teacher education. Physical Review Physics Education Research, 13(1), 1-16. https://doi.org/10.1103/PhysRevPhys EducRes.13.010111.

Supeno, S., Subiki, S., \& Rohma, L. W. (2018). Students' Ability In Solving Physics Problems on Newtons' Law of Motion. Jurnal Ilmiah Pendidikan Fisika Al-Biruni, $7(1), \quad 59$. https://doi.org/10.24042/jipfalbiruni.v $7 \mathrm{i} 1.2247$.

Susac, A., Bubic, A., Kazotti, E., Planinic, M., \& Palmovic, M. (2018). Student understanding of graph slope and area under a graph: A comparison of physics and nonphysics students. Physical Review Physics Education Research, 14(2), 20109. https://doi.org/10.1103/PhysRevPhys EducRes.14.020109.

Susac, A., Bubic, A., Martinjak, P., Planinic, M., \& Palmovic, M. (2017). Graphical representations of data improve student understanding of measurement and uncertainty: An eye-tracking study. 020125. 
https://doi.org/10.1103/PhysRevPhys EducRes.13.020125.

Teodorescu, R. E., Bennhold, C., Feldman, G., \& Medsker, L. (2013). New approach to analyzing physics problems: A Taxonomy of Introductory Physics Problems. 010103(January), 1-20. https://doi.org/10.1103/PhysRevSTP ER.9.010103.

Ubaidillah, M. (2016). Pengembangan LKPD Fisika Berbasis Problem Solving untuk Meningkatkan Keterampilan Proses Sains dan Keterampilan Berpikir Tingkat Tinggi. Jurnal EduFisika, 01(02), 920.
Widianingtiyas, L., Siswoyo, S., \& Bakri, F. (2017). Pengaruh Pendekatan Multi Representasi dalam Pembelajaran Fisika Terhadap Kemampuan Kognitif Siswa SMA. Jurnal Penelitian \& Pengembangan Pendidikan Fisika, 01(1), 31-38. https://doi.org/10.21009/1.01105.

Yuwono, G. R., Mahardika, I. ketut, \& Gani, A. A. (2016). Pengaruh Model Pembelajaran Inkuiri Terbimbing terhadap Hasil Belajar Fisika Siswa (Kemampuan Representasi Verbal, Gambar, Matematis, dan Grafik) di SMA. Jurnal Pembelajaran Fisika, 5(1), 60-65. 